\title{
The role of daily physical activity and nutritional status on bone turnover in cystic fibrosis: a cross-sectional study
}

Sergio Tejero ${ }^{1,2}$, Pilar Cejudo ${ }^{2}$, E. Quintana-Gallego ${ }^{2}$, Borja Sañudo ${ }^{1}$, A. Oliva-Pascual-Vaca ${ }^{1}$

ABSTRACT | Background: Nutritional status and daily physical activity (PA) may be an excellent tool for the maintenance of bone health in patients with cystic fibrosis (CF). Objective: To evaluate the relationship between nutritional status, daily physical activity and bone turnover in cystic fibrosis patients. Method: A cross-sectional study of adolescent and adult patients diagnosed with clinically stable cystic fibrosis was conducted. Total body, femoral neck, and lumbar spine bone mineral density (BMD) were determined by dual energy X-ray absorptiometry and bone metabolism markers ALP, P1NP, PICP, and ß-CrossLaps. PA monitoring was assessed for 5 consecutive days using a portable device. Exercise capacity was also determined. Serum 25-hydroxyvitamin D and vitamin K were also determined in all participants. Results: Fifty patients (median age: 24.4 years; range: 16-46) were included. BMI had positive correlation with all BMD parameters, with Spearman's coefficients ranging from 0.31 to 0.47 . Total hip bone mineral density and femoral neck BMD had positive correlation with the daily time spent on moderate PA $(>4.8$ metabolic equivalent-minutes $/$ day; $\mathrm{r}=0.74$, $\mathrm{p}<0.001$ and $\mathrm{r}=0.72 \mathrm{p}<0.001$ respectively), daily time spent on vigorous $\mathrm{PA}(>7.2$ metabolic equivalent-minutes/day; $r=0.45$ $\mathrm{p}<0.001)$, body mass index $(\mathrm{r}=0.44, \mathrm{p}=0.001)$, and muscle mass in limbs $(\mathrm{r}=0.41, \mathrm{p}=0.004)$. Levels of carboxy-terminal propeptide of type 1 collagen were positively associated with the daily time spent on moderate $(\mathrm{r}=0.33 \mathrm{p}=0.023)$ and vigorous PA $(r=0.53, p<0.001)$. Conclusions: BMI and the daily time spent on moderate PA were found to be correlated with femoral neck BMD in CF patients. The association between daily PA and biochemical markers of bone formation suggests that the level of daily PA may be linked to bone health in this patient group. Further research is needed to confirm these findings.

Keywords: cystic fibrosis; physical therapy; rehabilitation; nutritional status; bone remodeling; bone mineral density.

\section{BULLET POINTS}

- Physical therapy in cystic fibrosis patients is correlated with bone health.

- Bone health can improve with physical activity.

\section{HOW TO CITE THIS ARTICLE}

García ST, Cejudo P, Quintana-Gallego E, Sañudo B, Oliva-Pascual-Vaca A. The role of daily physical activity and nutritional status on bone turnover in cystic fibrosis: a cross-sectional study. Braz J Phys Ther. 2016 May-June; 20(3):206-212 http://dx.doi.org/10.1590/bjpt-rbf.2014.0154

\section{Introduction}

Thanks to advances in the treatment and care of patients with cystic fibrosis (CF), the life expectancy ${ }^{1}$ of these patients has increased. However, this fact has not resulted in quality of life because different comorbidities have been observed in adulthood. Disturbances in bone metabolism, particularly significant reductions in bone mineral density (BMD), are recognized as additional and serious complications in these CF patients, with prevalence ranging from $40 \%$ to $70 \%{ }^{2,3}$. The low BMD found in these patients is multifactorial and many factors have been suggested as explanation ${ }^{4-10}$. One of these explanations is based on intestinal malabsorption, with vitamin $\mathrm{D}$ deficiency caused by exocrine pancreatic insufficiency ${ }^{4}$. Evidence suggests that the absorption of vitamins D and $\mathrm{K}$ may not be sufficient to ensure proper skeletal mineralization in $\mathrm{CF}$ adolescents ${ }^{5}$. Another bone metabolic disorder found in CF patients is imbalance in bone turnover, with decreased bone formation as the predominant change and increased bone resorption in infective exacerbation or severe lung disease ${ }^{6-8}$. Moreover, severe lung disease also affects bone mass. Forced expiratory volume in one second $\left(\mathrm{FEV}_{1}\right)$ expressed as the percentage of the predicted value is a robust marker 
for lung disease and helps to explain the variability of BMD $^{9}$. This correlation is explained in part because severe lung disease adversely affects exercise capacity. When monitoring daily physical activity (PA), it was noted that the most active patients have greatest bone mass, confirmed by exercise capacity test ${ }^{10}$. Nevertheless, there is no confirmation of whether bone turnover has a relationship with PA and its intensity or with nutritional status. This study was designed to evaluate the relationship between daily level of PA, nutritional status, and bone parameters (BMD and biomarkers of bone turnover) in a sample of adolescents and adults with CF.

\section{Method}

\section{Participants and study design}

We conducted a cross-sectional study that included patients over 16 years of age diagnosed with $\mathrm{CF}$ and attending our Cystic Fibrosis Unit. All participants exhibited high sweat chloride levels ( $>60 \mathrm{mmol} / \mathrm{L})$, had characteristic clinical features of $\mathrm{CF}$, and their diagnoses were confirmed by repeated genetic analysis. Patients who had undergone lung transplantation and/or had a recent acute exacerbation requiring treatment with antibiotics (within 6 weeks prior to the study) were excluded. The Ethics Committee of the Virgen del Rocío Hospital, Sevilla, Spain approved this study (approval number 14/2008) and written informed consent was obtained from all participants.

\section{Maximal cardiopulmonary exercise testing}

In order to evaluate the tolerance to exercise, maximal cardiopulmonary exercise testing was performed with a MasterScreen CPX cycle ergometer model Via Sprint 150 (ViaSys Healthcare, Hoechberg, Germany), as previously described ${ }^{10}$ and according to the international standard $^{11}$. The test is a symptom-limited exercise and involves measurements of respiratory oxygen uptake $\left(\mathrm{VO}_{2}\right)$, carbon dioxide production $\left(\mathrm{VCO}_{2}\right)$, and ventilatory measures. It was performed with electrocardiographic, heart rate, and pulse oximetry monitoring. All measurements were integrated into the cycle ergometer device and evaluated simultaneously during the test. On completion of the exercise test, heart rate, blood pressure, leg fatigue, chest pain, and dyspnea were assessed using the modified Borg scale.

\section{Physical activity monitoring}

Physical activity was measured in all participants on five consecutive days using a portable physical activity and lifestyle monitor (SenseWear ${ }^{\circledR}$ Armband,
BodyMedia Inc., Pittsburgh, PA, USA), which estimates a person's rest and exercise energy expenditure. The accelerometer was positioned on the right brachial triceps and was only removed for showering ${ }^{12}$. The records were considered valid if the mean wearing time was $\geq 600 \mathrm{~min} /$ day in the 5 -day period and at least one of the five days landed on a weekend. The use of this device has been validated against doubly labeled water ${ }^{13}$. The time (in minutes) spent with an energy expenditure of $>3$ metabolic equivalent-minutes/day (METs) was considered "mild" activity, time spent at $>4.8$ METs was considered "moderate" activity, and when energy expenditure was of $>7.2$ METs, it was considered "vigorous" activity, as suggested by the U.S. Department of Health and Human Services ${ }^{14}$. The average number of daily steps at each intensity level was calculated in all participants.

\section{Nutritional assessment}

The values for lean muscle mass and fat mass were assessed in the extremities by dual energy X-ray absorptiometry $^{15}$ (DXA). Body mass index, serum albumin, and serum levels of vitamins D and $\mathrm{K}$ were determined in all participants. For biochemical assays, blood samples were drawn in the morning after an overnight fast. Concentrations of 25-hydroxyvitamin D (25OHD) were determined by high-performance liquid chromatography (HPLC) on an Agilent 1100 HPLC system (Agilent Technologies Inc., Santa Clara, CA, USA). Plasma vitamin K concentrations were assessed by means of HPLC.

\section{Bone mineral density and bone turnover biomarkers}

Total body, femoral neck, and lumbar spine (L1-L4) BMD were determined by dual-energy X-ray absorptiometry (Hologic QDR X-ray 4500W Bone Densitometer). DXA results were expressed in absolute BMD units (grams per square centimeter), T-scores, and Z-scores. The T-score was defined as the number of standard deviations above or below the mean for a healthy 20 -year-old adult of the same sex and ethnicity as the patient. The Z-score was defined as the number of standard deviations a patient's BMD differs from the average BMD of their age, sex, and ethnicity ${ }^{16}$.

Serum levels of $\beta$-CrossLaps and amino-terminal propeptide of type 1 collagen (P1NP) were measured using an electrochemiluminescence method on a Cobas e411 analyzer (Roche Diagnostics, Indianapolis, IN, USA). Bone-specific alkaline phosphatase (ALP) and 
serum levels of carboxy-terminal propeptide of type 1 collagen (P1CP) were assayed using ELISA (Quidel Corporation, San Diego, CA, USA) on an automated TRITURUS processor (Grifols International S.A., Barcelona, Spain).

\section{Statistical analysis}

The simple size calculation was estimated using the Dixon and Mansey formula ${ }^{17}$. This sample size was calculated using a power of $80 \%$ and a type I error of $5 \%$.

Continuous data were expressed as medians and interquartile ranges (Q3- Q1) and categorical data were expressed with relative frequencies. We performed a Mann-Whitney U test and Chi-Square test for comparisons between sex groups. The associations between functional and structural parameters were tested using the non-parametric Rho Spearman correlation. Spearman's rank correlation can be interpreted in terms of the amount of mutual information between two variables. An observed value of $\rho$ is significantly different from zero ( $\mathrm{r}$ will always maintain $-1 \leq \mathrm{r} \leq 1$ ). We calculated the probability that it would be greater than or equal to the observed $r$, given the null hypothesis, by using a permutation test. An advantage of this approach is that it automatically takes into account the number of tied data values in the sample and the way they are treated in computing the rank correlation. All tests were performed using 0.2 and 0.05 as the probability of a Type II error and probability of a Type I error, respectively.

All statistical calculations were performed using the SPSS 16.0 statistical software package (SPSS Inc., Chicago, IL, USA). Two-tailed $\mathrm{p}<0.05$ were considered statistically significant.

\section{Results}

We included 50 patients in our sample (23 males and 27 females) with a median age 24.4 (interquartile range - $\mathrm{IQR}=5.8$ ) years. A total of 48 patients $(96 \%)$ were undergoing oral corticosteroid treatment. Two of the patients (4\%) had been diagnosed with allergic bronchopulmonary aspergillosis (ABPA) and were being treated intermittently with prednisone (10 mg/day per os) for the last three years, and 23 patients (96\%) had also been receiving inhaled corticosteroids (budesonide) at doses of 200-400 $\mu \mathrm{g}$ administered twice a day. All patients were prescribed vitamin supplementation (Vitamin A $1.50 \mathrm{mg}$, Vitamin
D $0.01 \mathrm{mg}$, and Vitamin E $200 \mathrm{mg}$ ). There was no documented secondary hepatopathy in any patient.

The male patients showed more wattage, 130 vs 100 $(\mathrm{p}=0.001)$ and spent more time on a moderate activity 24 vs $11.6(p=0.045)$. There was no difference in the remaining parameters between sex groups. The general characteristics of the study participants are shown in Table 1.

\section{Nutritional status, bone mineral density, and markers}

Body mass index (BMI) showed a positive correlation with all of the BMD parameters, with Spearman's coefficient ranging from 0.31 to 0.47 . Muscle mass had a positive relationsip with all markers ranging from 0.48 to 0.43 for bone formation markers and 0.33 for serum levels of $\beta$-CrossLaps. In contrast, the percentage of fat mass had a negative correlation with the formation and resorption markers, ranging from -0.57 to -0.34 . A positive correlation was found between 25 -hydroxyvitamin $\mathrm{D}$ and whole-body $\mathrm{Z}$-scores $(\mathrm{r}=0.34, \mathrm{p}=0.03)$.

\section{Daily physical activity, bone mineral density, and markers}

Wattage showed a positive correlation with all BMD parameters. Spearman's coefficient, ranging from 0.30 to 0.49 , also showed a weak positive correlation with ALP $(r=0.29 \mathrm{p}=0.04)$.

All variables of daily physical activity (PA) had a positive correlation with at least two BMD parameters. The strongest correlation was found between the average number of minutes spent on moderate daily PA ( $>4.8$ METs $)$ and hip BMD $(r=0.74 p<0.001)$ (Table 2). Remodeling markers only had a positive correlation with moderate and vigorous daily PA with a higher coefficient in vigorous activity and formation markers. The relationship of bone formation markers with 4.8 METs and 7.2 METs is presented in Figure 1.

\section{Discussion}

The foundations for lifetime bone health are established from infancy to adolescence and require adequate nutrition, body mass, PA, and hormone production $^{18}$. CF compromises the gains during puberty when growth and mineral accrual are most rapid $^{19}$. The values of BMD found in our CF patients are consistent with previous findings ${ }^{2}$. Our results show that patients diagnosed with CF with high levels of daily PA have higher BMD values and increased 
Table 1. General characteristics of patients with cystic fibrosis stratified according to sex.

\begin{tabular}{|c|c|c|c|c|}
\hline & Total Cohort $(\mathrm{N}=\mathbf{5 0})$ & Males $(n=23)$ & Females $(n=27)$ & $\mathbf{p}$ \\
\hline \multicolumn{5}{|l|}{ Demographic data } \\
\hline Age years (IQR) & $24.5(19-28)$ & $25(19-30)$ & $24(20-27)$ & 0.59 \\
\hline Corticosteroids & $48(96)$ & $22(95.6)$ & $26(96.3)$ & 1.00 \\
\hline BMI Kg/m² (IQR) & $20.5(18.8-21.9)$ & $20.6(18.9-22.8)$ & $19.9(18.7-21.6)$ & 0.30 \\
\hline$\Delta \mathrm{F} 508$ mutation & $33(66.0)$ & $16(69.6)$ & $17(63.0)$ & 0.62 \\
\hline$\Delta \mathrm{F} 508$ homocigosis & $15(30.0)$ & $8(34.8)$ & $7(25.9)$ & 0.50 \\
\hline$\Delta \mathrm{F} 508$ heterocigosis & $18(36.0)$ & $8(34.8)$ & $10(37.0)$ & 0.87 \\
\hline R334W mutation & $10(20.0)$ & $6(26.1)$ & $4(14.8)$ & 0.32 \\
\hline Exocrine pancreatic insufficiency & $36(72.0)$ & $15(65.2)$ & $21(77.8)$ & 0.32 \\
\hline \multicolumn{5}{|l|}{ Exercise tolerance } \\
\hline $\mathrm{FEV}_{1 \%}$ predicted (IQR) & $60.3(35.2-80.9)$ & $47.4(35.2-80.8)$ & $60.7(32.6-82.6)$ & 1.00 \\
\hline FVC \% predicted (IQR) & $78.0(59.3-95.3)$ & $77(59.3-93.5)$ & $78.6(58.1-99.9)$ & 0.90 \\
\hline $\mathrm{VO}_{2} \max \%(\mathrm{IQR})$ & $66.5(58.0-81.5)$ & $65(58-75)$ & $72(60.9-89.0)$ & 0.22 \\
\hline Wmax (IQR) & $110(80-130)$ & $130(110-150)$ & $100(80-110)$ & 0.001 \\
\hline 6MWT distance meters (IQR) & $640(582-679)$ & $647(620-695)$ & $615(562-675)$ & 0.05 \\
\hline \multicolumn{5}{|l|}{ Daily physical activity } \\
\hline Device wearing min/day (IQR) & $618(598-637)$ & $614(598-643)$ & $622(589-634)$ & 0.63 \\
\hline PA >3 METs min/day (IQR) & $152(107-231)$ & $154(117-239)$ & $121(97-230)$ & 0.37 \\
\hline $\mathrm{PA}>4.8 \mathrm{METs} \min /$ day (IQR) & $11.6(5.5-35.4)$ & $24(6.25-56.55)$ & $10.2(3.5-16.6)$ & 0.04 \\
\hline $\mathrm{PA}>$ 7.2METs min/day (IQR) & $0.5(0-2.2)$ & $0.75(0.25-2.0)$ & $0.16(0-1.12)$ & 0.05 \\
\hline Steps/day (IQR) & $8,361(5,662-10,322)$ & $8,859(5,676-12,472)$ & $7,972(5,294-9,660)$ & 0.22 \\
\hline \multicolumn{5}{|l|}{ Osteoporosis } \\
\hline $\mathrm{Z}$ score $<1 \mathrm{SD}(\%)$ & $25(51.0)$ & $12(52.2)$ & $13(48.1)$ & 0.45 \\
\hline Z score <2 SD (\%) & $2(4)$ & $2(8.7)$ & $0(0)$ & 0.22 \\
\hline
\end{tabular}

IQR: interquartile range; $\mathrm{BMI}$ : body mass index; $\mathrm{FEV}_{1}$ : forced expiratory volume in one second; $\mathrm{FVC}$ : forced vital capacity; $\mathrm{VO}_{2}$ max $\%$ theoretical: maximal oxygen consumption; Wmax (watts): maximal power output; PA: physical activity; METs: metabolic equivalents (minutes/day). Data given as median (IQR).
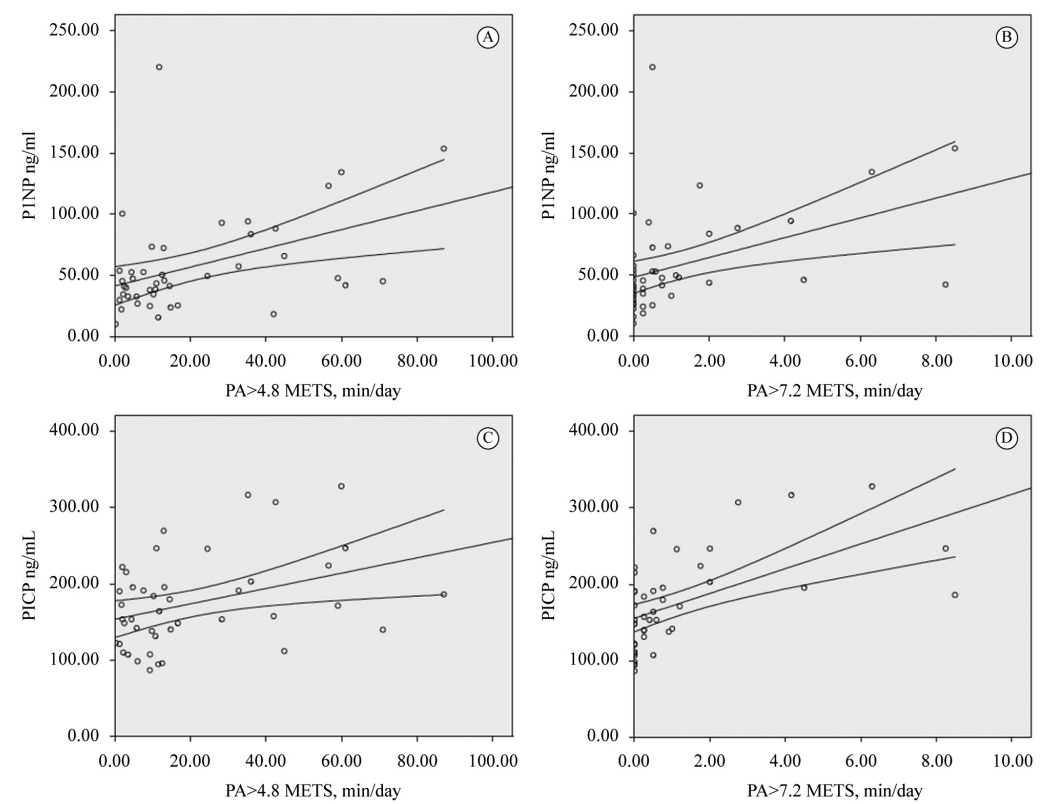

Figure 1. Correlation beetween bone formation markers and daily physical activity. (A) PA $>4.8 \mathrm{METs} \min /$ day versus P1NP ng/mL, $\mathrm{r}=0.35 \mathrm{p}=0.013$; (B) PA>7.2 METs min/day versus P1NP ng/mL, $\mathrm{r}=0.42 \mathrm{p}=0.003$; (C) PA>4.8 METs min/day versus PICP ng/mL, $\mathrm{r}=0.32$ $\mathrm{p}=0.023$; (D) PA $>7.2 \mathrm{METs} \mathrm{min} /$ day versus PICP ng/mL, $\mathrm{r}=0.53 \mathrm{p}<0.001$. 
Table 2. Spearman's correlations of exercise tolerance parameters, daily physical activity, and nutritional parameters with bone mineral density and bone turnover biomarkers in adult CF patients.

\begin{tabular}{|c|c|c|c|c|c|c|}
\hline & BMD & $\mathbf{r}$ & $\mathbf{p}$ & $\begin{array}{c}\text { Bone Turnover } \\
\text { Biomarkers }\end{array}$ & $\mathbf{r}$ & $\mathbf{p}$ \\
\hline \multicolumn{7}{|c|}{ EXERCISE TOLERANCE AND DAILY PHYSICAL ACTIVITY PARAMETERS } \\
\hline $\mathrm{PA}>3$ METs & $\begin{array}{l}\text { Lumbar spine } \\
\text { Total hip } \\
\text { Femoral neck } \\
\text { Whole body }\end{array}$ & $\begin{array}{l}0.17 \\
0.36 \\
0.28 \\
0.26\end{array}$ & $\begin{array}{l}0.254 \\
\mathbf{0 . 0 1} \\
\mathbf{0 . 0 4 8} \\
\mathbf{0 . 0 4 7}\end{array}$ & $\begin{array}{c}\text { P1NP } \\
\text { PICP } \\
\text { ALP } \\
\text { ß-CrossLaps }\end{array}$ & $\begin{array}{r}0.13 \\
0.18 \\
-0.01 \\
0.13\end{array}$ & $\begin{array}{l}0.366 \\
0.213 \\
0.927 \\
0.360\end{array}$ \\
\hline $\mathrm{PA}>4.8 \mathrm{METs}$ & $\begin{array}{l}\text { Lumbar spine } \\
\text { Total hip } \\
\text { Femoral neck } \\
\text { Whole body }\end{array}$ & $\begin{array}{l}0.58 \\
0.74 \\
0.72 \\
0.24\end{array}$ & $\begin{array}{r}<\mathbf{0 . 0 0 1} \\
<\mathbf{0 . 0 0 1} \\
<\mathbf{0 . 0 0 1} \\
0.098\end{array}$ & $\begin{array}{c}\text { P1NP } \\
\text { PICP } \\
\text { ALP } \\
\text { B-CrossLaps }\end{array}$ & $\begin{array}{l}0.35 \\
0.32 \\
0.29 \\
0.16\end{array}$ & $\begin{array}{l}\mathbf{0 . 0 1 3} \\
\mathbf{0 . 0 2 3} \\
\mathbf{0 . 0 4 3} \\
0.266\end{array}$ \\
\hline $\mathrm{PA}>7.2 \mathrm{METs}$ & $\begin{array}{l}\text { Lumbar spine } \\
\text { Total hip } \\
\text { Femoral neck } \\
\text { Whole body }\end{array}$ & $\begin{array}{l}0.20 \\
0.49 \\
0.34 \\
0.21\end{array}$ & $\begin{array}{r}0.168 \\
<\mathbf{0 . 0 0 1} \\
\mathbf{0 . 0 1 6} \\
0.149\end{array}$ & $\begin{array}{c}\text { P1NP } \\
\text { PICP } \\
\text { ALP } \\
\text { B-CrossLaps }\end{array}$ & $\begin{array}{l}0.42 \\
0.53 \\
0.36 \\
0.30\end{array}$ & $\begin{array}{r}0.003 \\
<0.001 \\
0.011 \\
0.037\end{array}$ \\
\hline \multicolumn{7}{|c|}{ NUTRITIONAL PARAMETERS } \\
\hline BMI $\left(\mathrm{Kg} / \mathrm{m}^{2}\right)$ & $\begin{array}{l}\text { Lumbar spine } \\
\text { Total hip } \\
\text { Femoral neck } \\
\text { Whole body }\end{array}$ & $\begin{array}{l}0.35 \\
0.44 \\
0.31 \\
0.48\end{array}$ & $\begin{array}{l}0.015 \\
0.001 \\
0.028 \\
0.001\end{array}$ & $\begin{array}{c}\text { P1NP } \\
\text { PICP } \\
\text { ALP } \\
\text { ß-CrossLaps }\end{array}$ & $\begin{array}{c}0.10 \\
-0.13 \\
0 \\
-0.04\end{array}$ & $\begin{array}{l}0.480 \\
0.369 \\
0.999 \\
0.804\end{array}$ \\
\hline Muscle mass (g) & $\begin{array}{l}\text { Lumbar spine } \\
\text { Total hip } \\
\text { Femoral neck } \\
\text { Whole body }\end{array}$ & $\begin{array}{l}0.03 \\
\mathbf{0 . 4 1} \\
0.16 \\
0.16\end{array}$ & $\begin{array}{l}0.819 \\
\mathbf{0 . 0 0 4} \\
0.275 \\
0.272\end{array}$ & $\begin{array}{c}\text { P1NP } \\
\text { PICP } \\
\text { ALP } \\
\text { ß-CrossLaps }\end{array}$ & $\begin{array}{l}0.48 \\
0.49 \\
0.43 \\
0.33\end{array}$ & $\begin{array}{r}<0.001 \\
<0.001 \\
\mathbf{0 . 0 0 2} \\
\mathbf{0 . 0 2 2}\end{array}$ \\
\hline Fat mass $(\%)$ & $\begin{array}{l}\text { Lumbar spine } \\
\text { Total hip } \\
\text { Femoral neck } \\
\text { Whole body }\end{array}$ & $\begin{array}{r}0.55 \\
-0.25 \\
-0.03 \\
-0.00\end{array}$ & $\begin{array}{l}0.711 \\
0.087 \\
0.837 \\
0.991\end{array}$ & $\begin{array}{c}\text { P1NP } \\
\text { PICP } \\
\text { ALP } \\
\text { ß-CrossLaps }\end{array}$ & $\begin{array}{l}-0.43 \\
-0.58 \\
-0.37 \\
-0.34\end{array}$ & $\begin{array}{r}0.002 \\
<0.001 \\
0.010 \\
0.017\end{array}$ \\
\hline $25 \mathrm{OHD}(\mathrm{nmol} / \mathrm{L})$ & $\begin{array}{l}\text { Lumbar spine } \\
\text { Total hip } \\
\text { Femoral neck } \\
\text { Whole body }\end{array}$ & $\begin{array}{l}0.14 \\
0.21 \\
0.30 \\
\mathbf{0 . 3 4}\end{array}$ & $\begin{array}{l}0.324 \\
0.150 \\
0.057 \\
\mathbf{0 . 0 3 4}\end{array}$ & $\begin{array}{c}\text { P1NP } \\
\text { PICP } \\
\text { ALP } \\
\text { ß-CrossLaps }\end{array}$ & $\begin{array}{r}0.06 \\
-0.15 \\
0.07 \\
0.02\end{array}$ & $\begin{array}{l}0.672 \\
0.313 \\
0.645 \\
0.896\end{array}$ \\
\hline VITAMIN K $(\mu \mathrm{g} / \mathrm{L})$ & $\begin{array}{l}\text { Lumbar spine } \\
\text { Total hip } \\
\text { Femoral neck } \\
\text { Whole body }\end{array}$ & $\begin{array}{r}0.01 \\
0.00 \\
-0.04 \\
0.07\end{array}$ & $\begin{array}{l}0.940 \\
0.991 \\
0.778 \\
0.651\end{array}$ & $\begin{array}{c}\text { P1NP } \\
\text { PICP } \\
\text { ALP } \\
\text { ß-CrossLaps }\end{array}$ & $\begin{array}{r}-0.09 \\
-0.14 \\
0.07 \\
0.04\end{array}$ & $\begin{array}{l}0.574 \\
0.319 \\
0.645 \\
0.805\end{array}$ \\
\hline
\end{tabular}

BMD: bone mineral density; METs: metabolic equivalents (minutes/day); P1NP: amino-terminal propeptide of type 1 collagen; P1CP: carboxyterminal propeptide of type 1 collagen; ALP: bone-specific alkaline phosphatase; BMI: body mass index; 25OHD: 25-hydroxyvitamin D.

serum levels of bone formation markers. The bone remodeling markers in our sample were significantly different from the reference values of the normal adult population.

Routine screening for reduced BMD using dual energy X-ray absorptiometry (DXA) scans is recommended as detailed in published guidelines ${ }^{2,20}$. The recommendation is for this procedure to be performed every 5 years, 2 years, or 1 year, depending on Z-score values in young adults. Bone loss has been observed in several longitudinal studies in young adults with $\mathrm{CF}^{21,22}$ reporting annualized losses in BMD of 0.5 to $2.1 \%$. This significant loss requires a more thorough investigation. The positive correlation found between $\mathrm{BMI}$ and the BMD values was in agreement with several previous studies ${ }^{9,23}$ and suggests that improving vigilance in the periods between DXA scans could result in an alternative marker.

Concerning vitamins, the normal rate of 25OHD in these patients was $20-40 \mathrm{ng} / \mathrm{mL}$. We only found a weak positive relationship between 25OHD and BMD values, although all patients had vitamin D supplementation. Recent meta-analyses show that vitamin D supplementation increases the levels of vitamin $\mathrm{D}$ in the blood but does not improve BMD values $^{24}$. This suggests that recommended vitamin 
supplementation is useful but insufficient for the maintenance of bone health in these patients ${ }^{2}$.

PA and exercise training play an important role in the clinical management of patients with cystic fibrosis $(\mathrm{CF})$. Exercise training is more common and recognized as an essential part of rehabilitation programs and overall CF care ${ }^{2,20}$. However, exercise remains underutilized and not always incorporated into the CF management routine.

Our results suggest that there is no correlation of turnover markers in PA with low intensity. However, when daily physical activity is moderate ( $>4.8$ METS) or vigorous (>7.2 METS), they are significantly correlated with circulating levels of bone formation markers. The present study is the first to demonstrate that vigorous daily PA may have a correlation with the rate of bone remodeling by favoring bone formation in adolescent and young adult $\mathrm{CF}$ patients. These findings suggest that the intensity of the exercise can have an influence on the bone turnover of CF patients and therefore should be controlled in the exercise prescriptions to improve bone health.

This is suggested in a review of weight-bearing exercise $^{25}$, which states that exercise prescriptions should generate bone strains that are not only of a sufficiently high magnitude, but also unusually distributed and high rate.

Published data on the amount of time spent on PA among patients with CF are limited. Although Troosters et al. ${ }^{12}$ have previously described the use of accelerometers to monitor daily PA in this population group, they did not focus the possible effects on BMD nor on bone remodeling markers. In contrast, other authors have established models in which a patient's maximal oxygen consumption $\left(\mathrm{VO}_{2} \max \right)$ could be used as a BMD predictor ${ }^{26,27}$.

There are some limitations to the present study. First, results on bone turnover markers in CF patients should be interpreted with caution. In particular, levels of bone turnover markers may be altered in a specific subset of CF patients with impaired liver function. In addition, alterations in BMI, use of steroids, changes in lifestyle, and other variables may have confounded the results of bone turnover markers. The cross-sectional nature of our study means that the effect of exercise on bone metabolism was collected retrospectively and there was no control of vitamin supplementation adherence. Nevertheless, it should be noted that exercise is unlikely to result in short-term changes in bone turnover markers ${ }^{28}$. Future longitudinal studies with long follow-up periods are needed to confirm and expand our findings.

Despite these limitations, BMI and daily time spent on moderate physical activity were found to be correlated with femoral neck BMD in CF patients. The correlation between daily PA and biochemical markers of bone formation suggests that exercise is linked to bone health in this patient group. Further longitudinal studies are needed in order to confirm these findings.

\section{Conclusion}

BMI and daily time spent on moderate PA were found to be correlated with femoral neck BMD in CF patients. The correlation between daily PA and biochemical bone formation markers suggests that moderate and vigorous levels of PA may improve bone health in this population. Further research is needed in order to confirm these findings.

\section{Acknowledgments}

We would like to thank the cystic fibrosis patients who took the time out of their busy lives to participate in the study. The authors are grateful to Juan Manuel Praena Fernández from the Methodology and Research Evaluation Unit at the Virgen del Rocío University Hospital for his valuable statistical advice. We thank the Andalusian Cystic Fibrosis Association for their unconditional support. The authors also wish to acknowledge the cooperation of Dr. Luis Jiménez Jiménez and Inmaculada Domínguez from the Biochemistry Laboratory Department, Virgen del Rocío University Hospital, Seville, Spain. This study was supported by a grant from the Association of Pulmonologists of Southern Spain (Neumosur).

\section{References}

1. Boyle MP. Adult cystic fibrosis. JAMA. 2007;298(15):1787-93. http://dx.doi.org/10.1001/jama.298.15.1787. PMid:17940235.

2. Aris RM, Merkel PA, Bachrach LK, Borowitz DS, Boyle MP, Elkin SL, et al. Guide to bone health and disease in cystic fibrosis. J Clin Endocrinol Metab. 2005;90(3):188896. http://dx.doi.org/10.1210/jc.2004-1629. PMid:15613415.

3. Castellani C, Malerba G, Sangalli A, Delmarco A, Petrelli E, Rossini M, et al. The genetic background of osteoporosis in cystic fibrosis: association analysis with polymorphic markers in four candidate genes. J Cyst Fibros. 2006;5(4):229-35. http://dx.doi.org/10.1016/j.jcf.2006.03.008. PMid:16713399.

4. Paccou J, Zeboulon N, Combescure C, Gossec L, Cortet B. The prevalence of osteoporosis, osteopenia, and fractures 
among adults with cystic fibrosis: a systematic literature review with meta-analysis. Calcif Tissue Int. 2010;86(1):1-7. http://dx.doi.org/10.1007/s00223-009-9316-9. PMid:19949942.

5. Grey V, Atkinson S, Drury D, Casey L, Ferland G, Gundberg $\mathrm{C}$, et al. Prevalence of low bone mass and deficiencies of vitamins $\mathrm{D}$ and $\mathrm{K}$ in pediatric patients with cystic fibrosis from 3 Canadian centers. Pediatrics. 2008;122(5):1014-20. http://dx.doi.org/10.1542/peds.2007-2336. PMid:18977981.

6. Aris RM, Stephens AR, Ontjes DA, Denene Blackwood A, Lark RK, Hensler MB, et al. Adverse alterations in bone metabolism are associated with lung infection in adults with cystic fibrosis. Am J Respir Crit Care Med. 2000;162(5):1674-8. http://dx.doi.org/10.1164/ajrcem.162.5.2002100. PMid:11069795.

7. Shead EF, Haworth CS, Barker H, Bilton D, Compston JE. Osteoclast function, bone turnover and inflammatory cytokines during infective exacerbations of cystic fibrosis. J Cyst Fibros. 2010;9(2):93-8. http://dx.doi.org/10.1016/j. jcf.2009.11.007. PMid:20006563.

8. Penafortes JT, Guimarães FS, Moço VJ, Almeida VP, Menezes SL, Lopes AJ. Relationship between body balance, lung function, nutritional status and functional capacity in adults with cystic fibrosis. Braz J Phys Ther. 2013;17(5):450-7. http://dx.doi.org/10.1590/S1413-35552012005000111. PMid:24037240.

9. Buntain HM, Greer RM, Schluter PJ, Wong JC, Batch JA, Potter JM, et al. Bone mineral density in Australian children, adolescents and adults with cystic fibrosis: a controlled cross sectional study. Thorax. 2004;59(2):149-55. http:// dx.doi.org/10.1136/thorax.2003.006726. PMid:14760157.

10. Tejero García S, Giráldez Sánchez MA, Cejudo P, Quintana Gallego E, Dapena J, García Jiménez R, et al. Bone health, daily physical activity, and exercise tolerance in patients with cystic fibrosis. Chest. 2011;140(2):475-81. http://dx.doi. org/10.1378/chest.10-1508. PMid:21292759.

11. American Thoracic Society, American College of Chest Physicians. ATS/ACCP statement on cardiopulmonary exercise testing. Am J Respir Crit Care Med. 2003;167:11-227.

12. Troosters T, Langer D, Vrijsen B, Segers J, Wouters K, Janssens W, et al. Skeletal muscle weakness, exercise tolerance and physical activity in Adults with cystic fibrosis. Eur Respir J. 2009;33(1):99-106. http://dx.doi. org/10.1183/09031936.00091607. PMid:18715878.

13. St-Onge M, Mignault D, Allison DB, Rabasa-Lhoret R. Evaluation of a portable device to measure daily energy expenditure in free-living adults. Am J Clin Nutr. 2007;85(3):742-49. PMid:17344495.

14. US Department of Health and Human Services. Physical Activity and Health: a report of the surgeon general. Atlanta: US Department of Health and Human Services, Public Health Service, CDC, National Center for Chronic Disease Prevention and Health Promotion; 1996.

15. Sheahan NF, Dowling A, O'Reilly G, Malone JF. Commissioning and quality assurance protocol for dual energy X-ray absorptiometry systems. Radiat Prot Dosimetry. 2005;117(1-3):288-90. http://dx.doi.org/10.1093/rpd/nci741. PMid:16461504.

16. Kanis JA, Melton LJ 3rd, Christiansen C, Johnston CC, Khaltaev N. The diagnosis of osteoporosis. J Bone Miner Res. 1994;9(8):1137-41. http://dx.doi.org/10.1002/jbmr.5650090802. PMid:7976495.
17. Dixon WJ, Massey FJ Jr, editors. Introduction to statistical analysis. 4th ed. New York: McGrawHill; 1983. 224 p.

18. Bachrach LK. Acquisition of optimal bone mass in childhood and adolescence. Trends Endocrinol Metab. 2001;12(1):228. http://dx.doi.org/10.1016/S1043-2760(00)00336-2. PMid:11137037.

19. Bailey DA, McKay HA, Mirwald RL, Crocker PR, Faulkner RA. A six-year longitudinal study of the relationship of physical activity to bone mineral accrual in growing children: the university of Saskatchewan bone mineral accrual study. J Bone Miner Res. 1999;14(10):1672-9. http:// dx.doi.org/10.1359/jbmr.1999.14.10.1672. PMid:10491214.

20. Sermet-Gaudelus I, Bianchi ML, Garabédian M, Aris RM, Morton A, Hardin DS, et al. European cystic fibrosis bone mineralisation guidelines. J Cyst Fibros. 2011;10(Suppl 2):S16-23. http://dx.doi.org/10.1016/S1569-1993(11)60004-0. PMid:21658635.

21. Haworth CS, Selby PL, Horrocks AW, Mawer EB, Adams JE, Webb AK. A prospective study of change in bone mineral density over one year in adults with cystic fibrosis. Thorax. 2002;57(8):719-23. http://dx.doi.org/10.1136/thorax.57.8.719. PMid:12149534.

22. Aris RM, Lester GE, Caminiti M, Blackwood AD, Hensler M, Lark RK, et al. Efficacy of alendronate in adults with cystic fibrosis with low bone density. Am J Respir Crit Care Med. 2004;169(1):77-82. http://dx.doi.org/10.1164/ rccm.200307-1049OC. PMid:14563654.

23. Legroux-Gérot I, Leroy S, Prudhomme C, Perez T, Flipo RM, Wallaert B, et al. Bone loss in adults with cystic fibrosis: prevalence, associated factors, and usefulness of biological markers. Joint Bone Spine. 2012;79(1):73-7. http://dx.doi. org/10.1016/j.jbspin.2011.05.009. PMid:21733729.

24. Ferguson JH, Chang AB. Vitamin D supplementation for cystic fibrosis. Cochrane Database Syst Rev. 2014;5:CD007298. PMid:24823922.

25. Hind K, Truscott JG, Conway SP. Exercise during childhood and adolescence: a prophylaxis against cystic fibrosis-related bone mineral density? Exercise for bone health in children with cystic fibrosis. J Cyst Fibros. 2008;7(4):270-6. http:// dx.doi.org/10.1016/j.jcf.2008.02.001. PMid:18378195.

26. Frangolias DD, Paré PD, Kendler DL, Davidson AGF, Wong L, Raboud J, et al. Role of exercise and nutrition status on bone mineral density in cystic fibrosis. J Cyst Fibros. 2003;2(4):163-70. http://dx.doi.org/10.1016/S15691993(03)00087-0. PMid:15463868.

27. Dodd JD, Barry SC, Barry RBM, Cawood TJ, McKenna MJ, Gallagher CG. Bone mineral density in cystic fibrosis: benefit of exercise capacity. J Clin Densitom. 2008;11(4):537-42. http://dx.doi.org/10.1016/j.jocd.2008.05.095. PMid:18619882.

28. Maïmoun L, Sultan C. Effects of physical activity on bone remodeling. Metabolism. 2011;60(3):373-88. http://dx.doi. org/10.1016/j.metabol.2010.03.001. PMid:20359721.

\author{
Correspondence \\ Sergio Tejero García \\ Department of Trauma and Orthopedic Surgery \\ Hospital Universitario Virgen del Rocío \\ Av. Manuel Siurot, s/n \\ 41013, Sevilla, Spain \\ e-mail: tejerogarciasergio@gmail.com
}

